\title{
The role of race and environment in the development of hyperosmolar hyperglycaemic non-ketotic coma
}

\author{
GRAHAM KNIGHT \\ M.B., M.R.C.P.
}

\author{
BRIAN A. LeATHERDALE \\ M.B., M.R.C.P.
}

Department of Diabetes and Endocrinology, Dudley Road Hospital, Birmingham

\begin{abstract}
Summary
In a retrospective study of patients presenting with hyperosmolar hyperglycaemic non-ketotic coma no evidence was obtained to suggest that the condition occurs more commonly in black patients. Suspicions that poor social background rather than race predisposes patients to the condition are borne out by the fact that 10 of the 13 patients were socially isolated.
\end{abstract}

\section{Introduction}

It has been reported that hyperosmolar hyperglycaemic non-ketotic coma (HHNC) occurs more commonly in black patients (Pyke, 1969) and this has become an accepted part of clinical teaching on the subject (Oakley, Pyke and Taylor, 1978; Jackson and Vinik, 1977). Recently this point has been further emphasized (Nikolaides et al., 1981; Wright et al., 1981). Our personal observations however suggested that poor social circumstances might be more important than racial factors in the aetiology of HHNC. A retrospective analysis of patients with the condition presenting to Dudley Road Hospital, Birmingham, a district general hospital serving a substantial immigrant population, was thus undertaken.

\section{Methods}

Patients with HHNC were identified by examining the records of patients admitted with the diagnosis of diabetic coma to the Intensive Care Unit and medical wards from 1976 to 1980 . The criteria for the diagnosis of HHNC were: impairment of consciousness, no significant ketosis, serum bicarbonate greater than $15 \mathrm{mmol} / \mathrm{l}$ (Pyke, 1969) and calculated serum osmolarity greater than 350 mosmol/1 (Podolsky, 1978). (Serum osmolarity was calculated from the formula: $2 \times\left[\left(\mathrm{Na}^{+} \mathrm{mmol} / \mathrm{l}+\mathrm{K}^{+} \mathrm{mmol} / \mathrm{l}\right)\right.$ +glucose $\mathrm{mmol} / \mathrm{l}+$ urea $\mathrm{mmol} / \mathrm{l}]$ ). To assess the expected proportion of black patients in the series the ethnic origin of patients attending the diabetic clinic during a 6-week period was examined.

\footnotetext{
Requests for reprints: Dr G. Knight, Floor P, Royal Hallamshire Hospital, Sheffield S10 2JF.
}

\section{Results}

Thirteen patients fulfilled the above criteria for inclusion in the study (Table 1). There were 8 females and 5 males of mean age 63 years (range 43-77). Initial biochemical findings included a mean blood glucose of $56 \mathrm{mmol} / 1$ (range 20.8-102 $\mathrm{mmol} / \mathrm{l}$ ), serum osmolarity $396 \mathrm{mosmol} / \mathrm{l}$ (range $350-449$ ) and serum bicarbonate $18.6 \mathrm{mmol} / 1$ (range 15-26.3). A detailed summary of biochemical results is given in Table 2 which also gives the outcome of management of the coma and eventual treatment.

No patient was a known diabetic. All patients were from social classes 4 and 5 ; 3 were black, 2 Asian and 8 European. Five patients lived alone, one was a long-term psychiatric inpatient, one elderly woman lived with her mentally ill son, 2 patients lodged with relatives and only 4 patients were married and living with their spouse. All the black patients were bachelors who lived alone.

Seven patients were taking drugs, one patient a beta-blocker, one a diuretic and 5 were on psychotropic drugs. Two depressed patients were taking tricyclic antidepressants and 3 patients with senile dementia were taking phenothiazines.

Four patients only were in employment, one was unemployed, 6 were pensioners and 2 were housewives. Only 2 patients enjoyed the combined social benefit of full-time employment and living at home with a spouse.

\section{Discussion}

Various factors have been associated with the development of HHNC including drugs-particularly corticosteroids and diuretics, concentrated glucose drinks, and serious underlying illness and race (Jackson and Vinik, 1977). Advancing age and previously undiagnosed diabetes have also been emphasized (Oakley et al., 1978; Podolsky, 1978).

In this study HHNC occurred most commonly in elderly, undiagnosed diabetics taking medication. Five of 13 cases were taking psychotropic drugs and only one was on a diuretic. One patient was known to 
TABLE 1. Some clinical features and serum osmolarities in the 13 patients studied with hyperosmolar non-ketotic diabetic coma

\begin{tabular}{|c|c|c|c|c|c|}
\hline Patient & $\begin{array}{c}\text { Serum } \\
\text { osmolarity } \\
\text { (mosmol/l) }\end{array}$ & Race & Environment & Mental condition & Marital status \\
\hline $\begin{array}{l}\text { A } \\
\text { B } \\
\text { C } \\
\text { D } \\
\text { E } \\
\text { F } \\
\text { G } \\
\text { H } \\
\text { I } \\
\text { J } \\
\text { K } \\
\text { L } \\
\text { M }\end{array}$ & $\begin{array}{l}449 \\
434 \\
412 \\
407 \\
406 \\
403 \\
399 \\
397 \\
391 \\
374 \\
371 \\
360 \\
350\end{array}$ & $\begin{array}{l}\text { W } \\
\text { B } \\
\text { A } \\
\text { W } \\
\text { W } \\
\text { B } \\
\text { W } \\
\text { B } \\
\text { A } \\
\text { W } \\
\text { W } \\
\text { W } \\
\text { W }\end{array}$ & $\begin{array}{l}\text { Psychiatric inpatient } \\
\text { Living alone } \\
\text { Living with spouse } \\
\text { Living alone } \\
\text { Living with spouse } \\
\text { Living alone } \\
\text { Living alone } \\
\text { Living alone } \\
\text { Living with spouse } \\
\text { Living with son } \\
\text { Living with sister } \\
\text { Living with son } \\
\text { Living with spouse }\end{array}$ & $\begin{array}{l}\text { Dementia } \\
\text { Depression } \\
\text { Depression } \\
\text { Dementia } \\
\text { Dementia }\end{array}$ & $\begin{array}{l}\text { Widow } \\
\text { Bachelor } \\
\text { Married } \\
\text { Widow } \\
\text { Married } \\
\text { Bachelor } \\
\text { Widow } \\
\text { Bachelor } \\
\text { Married } \\
\text { Separated } \\
\text { Widow } \\
\text { Widow } \\
\text { Married }\end{array}$ \\
\hline
\end{tabular}

$\mathrm{W}=$ white $; \mathrm{B}=$ black $; \mathrm{A}=$ Asian.

TABLE 2. Summary of biochemical details on admission, outcome of treatment and treatment on discharge

\begin{tabular}{|c|c|c|c|c|c|c|}
\hline Patient & $\begin{array}{c}\text { Serum } \\
\text { sodium } \\
(\mathrm{mmol} / \mathrm{l})\end{array}$ & $\begin{array}{c}\text { Blood } \\
\text { glucose } \\
(\mathrm{mmol} / \mathrm{l})\end{array}$ & $\begin{array}{c}\text { Blood } \\
\text { urea } \\
(\mathrm{mmol} / \mathrm{l})\end{array}$ & Outcome & $\begin{array}{l}\text { Treatment on discharge } \\
\text { from hospital }\end{array}$ & \\
\hline A & 150 & $64 \cdot 5$ & $75 \cdot 0$ & Recovered & Insulin & \\
\hline B & 170 & $46 \cdot 5$ & $24 \cdot 6$ & Recovered & Insulin & \\
\hline C & 118 & $102 \cdot 0$ & $62 \cdot 1$ & Recovered & Insulin & \\
\hline D & 155 & $50 \cdot 0$ & $47 \cdot 5$ & Recovered & Insulin & \\
\hline $\mathbf{E}$ & 134 & $82 \cdot 5$ & $44 \cdot 0$ & Died & - & \\
\hline $\mathrm{F}$ & 156 & $75 \cdot 0$ & $11 \cdot 5$ & Recovered & Insulin & \\
\hline G & 157 & $45 \cdot 0$ & $31 \cdot 5$ & Recovered & Insulin & 음 \\
\hline $\mathbf{H}$ & 158 & $55 \cdot 0$ & $30 \cdot 5$ & Recovered & Oral hypoglycaemics & 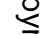 \\
\hline I & 164 & $21 \cdot 0$ & $45 \cdot 6$ & Recovered* & - & बे. \\
\hline $\mathbf{J}$ & 133 & $72 \cdot 3$ & $31 \cdot 5$ & Recovered & Diet alone & 2 \\
\hline $\mathbf{K}$ & 153 & $33 \cdot 5$ & $23 \cdot 2$ & Recovered* & - & \\
\hline $\mathrm{L}$ & 145 & $27 \cdot 3$ & $36 \cdot 0$ & Recovered* & - & \\
\hline $\mathbf{M}$ & 131 & $55 \cdot 0$ & $25 \cdot 0$ & Recovered & Oral hypoglycaemics & \\
\hline
\end{tabular}

*These patients were treated successfully for HHNC but died subsequently (2 from pneumonia and 1 from circulatory collapse).

have consumed large quantities of 'Lucozade', a glucose-containing proprietary drink, but in most cases such information was probably not sought. In one case serious illness (fractured femur) could have been a contributing factor.

Assessment of patients attending the diabetic clinic revealed that of an average weekly attendance of $81,19 \%$ were black, $24 \%$ Asian and $57 \%$ European, giving an expected figure in 13 random cases of 2 blacks, 3 Asian and 8 Europeans. Comparing this with the actual number of 3 blacks, 2 Asians and 8 Europeans, major racial differences in susceptibility to HHNC are not suggested. From Table 1 it can be seen that the patients with the highest serum osmolarity tended to be those who lived alone and this suggests that social isolation may be a powerful factor predisposing to HHNC If one accepts that social isolation is a feature of mental illness then 10 out of 13 patients were socially isolated.

Wright et al., (1981) state that 4 out of 15 patients with HHNC in their study were West Indians and this represents an excess number of West Indians presenting with HHNC. The authors do not, however, give the number of West Indians expected to 음 present with HHNC. Nikolaides et al. (1981) describe an increased occurrence of HHNC in West $\frac{5}{3}$ Indians presenting in diabetic coma and state that this may be related to the fact that the great majority of West Indians attending their clinic are non-insulin dependent but acknowledge that this does not ex- 옹 plain the high frequency of hyperosmolar coma as $>$ distinct from ketoacidosis in West Indians compared with the Caucasian population. They suggest that $N$ diabetics of West Indian origin have a different pattern of disease from the rest of the diabetic clinic population.

We suggest that the incidence of HHNC is related to social isolation rather than race, socially isolatedo patients being less likely to seek medical attention $\bar{\varnothing}$ at an early stage of their illness and thereby go on to $\stackrel{?}{+}$ develop hyperosmolar coma. The three black $\overparen{T}$ patients in our study were all socially isolated and $\stackrel{\vec{D}}{\circ}$ 
it is quite possible that there is a high level of social isolation among black immigrants to Britain. We propose that these factors may explain the high prevalence of HHNC among West Indians in other studies. Clinicians should continue to be alert to the diagnosis of HHNC in the elderly, confused patient, and not be misled by the lack of a previous history of diabetes. If the condition of a patient who is socially isolated deteriorates then the diagnosis of hyperosmolar coma/pre-coma should be considered.

\section{References}

JACKson, W.P.U. \& VINIK, A.I. (1977) Diabetes Mellitus,
Clinical and Metabolic. Edward Arnold, London, p. 145. Nikolaides, K., Barnett, A.H., Splliopoulos, A.J. \& WATKINS, P.J. (1981) West Indian diabetic population of a large inner city diabetic clinic. British Medical Journal, 283, 1374.

OAkley, G., Pyke, D.A. \& TAYlor, K.W. (1978) Diabetes and its Management. Blackwell Scientific Publications, Oxford, p. 132.

Podolsky, S. (1978) Hyperosmolar nonketotic coma in the elderly diabetic. Medical Clinics of North America, 62, 815 .

PYke, D.A. (1969) Diabetic ketosis and coma. Journal of Clinical Pathology, 22 (suppl. 2), 61.

Wright, A.D., Walsh, C.H., Fitzgerald, M.D. \& Malins J.M. (1981) Low dose insulin treatment of hyperosmolar diabetic coma. Postgraduate Medical Journal, 57, 556. 